\title{
Genç Kadınlarda İnvaziv Meme Kanseri Histopatolojik Özellikleri ve Hormon Reseptörleri
}

\section{Invasive Breast Cancer Histopathological Properties and Hormone Receptors in Young Women}

\author{
Pinar CELEPLİ, Salih CELEPLİ, İrem BİGAT, Sema HÜCÜMENOĞLU ${ }^{4}$ \\ 1 Ankara Eğitim ve Araştırma Hastanesi, Patoloji Bölümü, Ankara, Türkiye \\ 2 Gülhane Eğitim ve Araștırma Hastanesi, Genel Cerrahi, Ankara, Türkiye \\ 3 TOBB Ekonomi ve Teknoloji Üniversitesi, Biyomedikal Mühendisliği, Ankara, Türkiye \\ 4 Ankara Eğitim ve Araştırma Hastanesi, Patoloji Bölümü, Ankara, Türkiye
}

Yazışma Adresi

Correspondence Address

\section{Pinar CELEPLI}

Ankara Eğitim ve Araştırma Hastanesi, Patoloji Bölümü,

Ankara, Türkiye

pcelepli@yahoo.com

Geliș tarihi / Received : Tem 14, 2020 Kabul tarihi / Accepted : Ağu 21, 2020 Elektronik yayın tarihi : Eyl 01, 2021 Online published

Bu makalede yapılacak atıf:

Cite this article as:

Celepli P, Celepli S,

Bigat İ, Hücümenoğlu S.

Genç Kadınlarda İnvaziv Meme

Kanseri Histopatolojik Özellikleri

ve Hormon Reseptörleri

Akd Tip D / 2021; 7(3):372-376

Pinar CELEPLI

ORCID ID: 0000-0001-7643-6263 Salih CELEPLI

ORCID ID: 0000-0002-3596-7938 İrem BİGAT

ORCID ID: 0000-0003-0067-1675 Sema HÜCÜMENOĞLU

ORCID ID: 0000-0002-6898-4101

\section{ÖZ}

Amaç:

Meme kanseri, özellikle ileri yaş kadınlarda yaygındır. Genç kadınlarda da kansere bağlı ölümlerin önde gelen nedenleri arasındadır. Genç kadınlarda survey daha kısa olup, medikal tedaviye cevap daha düşük olmaktadır, nedeni bu hasta grubunda görülen kanser olgularının diğer yaş gruplarında görülenlerden farklı olarak kanser hücrelerinde izlenen hormon reseptörlerindeki farklılıklar olarak düşünülmektedir. Çalışmamızdaki amaç 40 yaş altı kadınlarda meme kanserinin klinik, histopatolojik özellikleri, ve hormon reseptörleri değerlendirip, bu yaştaki hastalara uygulanacak medikal tedavilerde farklı yöntemler geliştirilmesi için veri setleri oluşturmaktır.

\section{Gereç ve Yöntemler:}

Hastanemiz patoloji kliniğinde tanı almış 40 yaş altı 72 invaziv meme karsinom vakası; lokalizasyon, tümör büyüklüğü, histolojik grade, lenf nodu tutulumu, multifokalite/multisentrisite, uzak organ metastaz1, hormon reseptör (Östrojen-ER, progesteron-PR) durumu, HER2 ve ki-67 proliferasyon belirteçleri retrospektif olarak incelendi.

\section{Bulgular:}

Hastaların yaş ortalaması 35.31 olup, \%59.7'si sağ memede lokalizedir. Duktal karsinoma en yaygın histolojik tip olup, olguların \%52.8'inde yüksek grade saptandı. Vakaların büyük çoğunluğu ER (\%87.5) ve PR (\%73.6) pozitif, HER2 (\%83.3) negatif bulundu. Ki-67 proliferasyon indeksi $\% 52.8$ 'inde yüksek oranda izlendi.

\section{Sonuçlar:}

Bu bulgularla genç kadınlarda izlenen meme kanseri tümörlerinin daha yüksek histolojik grade ve yüksek proliferasyon indeksine sahip olduğunu göstermektedir. Bu nedenle bu yaş grubunda görülen kanserlerin biyolojik olarak daha agresif seyredeceğini ve prognozun kötü olacağını göstermektedir.

Anahtar kelimeler: Meme Kanseri, Genç Kadın, Histopatolojik Özellikleri, Hormon Reseptörleri

\section{ABSTRACT \\ Objective:}

Breast cancer is common, especially in older women. It is also one of the leading causes of cancer-related deaths in young women. Survey in young women is shorter and the response to 
medical treatment is lower, because cancer cases in this group of patients are considered as differences in hormone receptors in cancer cells, unlike those seen in other age groups. The aim of our study is to evaluate the clinical, histopathological features, and hormone receptors of breast cancer in women under the age of 40, and to create datasets to develop different methods in medical treatments to be applied to patients of this age.

\section{Material and Methods:}

Localization, tumor size, histological grade, lymph node involvement, multifocality/multicentricity, distant organ metastasis, hormone receptor (Estrogen-ER, progesterone-PR) status, HER2 and ki-67 proliferation markers were retrospectively analyzed in 72 invasive breast carcinoma cases under the age of 40 diagnosed in the pathology clinic of our hospital.

\section{Results:}

The average age of the patients is 35.31 and $59.7 \%$ of them are localized in the right breast. Ductal carcinoma is the most common histological type, and high grade was detected in $52.8 \%$ of cases. The majority of cases were ER $(87.5 \%)$ and PR (73.6 \%) positive, HER2 (83.3\%) negative. Ki-67 proliferation index was observed at a high rate in $52.8 \%$.

\section{Conclusion:}

These findings show that breast cancer tumors observed in young women have higher histological grade and high proliferation index. Therefore, it shows that cancers seen in this age group will progress more biologically and the prognosis will be poor.

Key words: Breast Cancer, Histopathological Features, Hormone Receptors, Young Woman

\section{GíRiş}

Meme kanseri kadınlarda görülen en sık malignitedir. Kadınlarda akciğer kanserinden sonra ikinci en önemli kanserden ölüm nedenidir (1). Meme kanserlerinin sadece \%5-7'si 40 yaş altı genç kadınlarda görülmektedir. Son dönemlerdeki çalışmalar bu yaş grubunda meme kanseri görülme sıklığının arttığını göstermektedir (2,3). Bazı klinik çalışmalar genç kadınlarda görülen meme kanseri olgularında yüksek tümör derecesi ve negatif hormon reseptör durumu olduğunu göstermiştir. Bu nedenle bu yaş grubunda meme kanseri olgularının kötü prognozlu ve klinik olarak agresif seyirli olduğu bildirilmiştir $(4,5)$. Ayrıca genç kadınlarda görülen meme kanseri olgularında kötü prognozlu subtip olan triple negatif tümörlerin daha yüksek oranda bulunduğu bildirilmiştir (6). Meme kanserinde genç yaşın prognoz üzerine bağımsız bir faktör olduğu tartışmalıdır. Bununla birlikte birçok çalışmada genç yaşın meme kanserli olgularda daha geniş agresif tedaviler uygulandığında bile yüksek nüks ve ölüm riskiyle ilişsili bağımsız bir faktör olduğu düşünülmektedir (7-10).

Meme kanseri güncel tedavi yaklaşımı multimodaldir. Cerrahi tedaviye ek radyoterapi, kemoterapi (adjuvan, neoadjuvan) ve endokrin tedavi uygulanmaktadır (11). Tedaviye direncin ana nedeni hastalar arasında ve her bir bireysel tümörde gözlenen tümör heterojenliğidir (12). Bu çalışmada, genç kadınlarda görülen meme kanseri olgularında heterojeniteyi ve karmaşık yapıyı açıklayan histopatolojik özelliklerinin hormon reseptörleri ve proliferasyon belirteçleri ile ilişkisini değerlendirdik.

\section{GEREÇ VE YÖNTEMLER}

Hastanemiz Patoloji kliniğinde Ocak 2015- Ocak 2020 yılları arasında 40 yaş altı invaziv karsinom tanısı almış 72 meme kanserli hastanın kayıtları retrospektif olarak tarandı. Tümör büyüklügüu, histolojik tümör tipi, lenf nodu tutulumu, hormon reseptör (ER,PR) durumu, HER2 (Human Epidermal Growth Factor 2) durumu, Ki-67 proliferasyon indeksi, bilateralite/multisentrisite, uzak organ metastazı ve tümör moleküler sınıflandirması incelendi. Histolojik grade modifiye Scarff-Bloom-Richardson gradeleme sistemi kullanılarak tümörün içerdiği tubül formasyonu, mitoz sayısı ve nükleer pleomorfizm tespit edilerek 1-3 olarak puanlama yapıldı (13). ER ve PR boyanmalarını değerlendirmek için boyanma yüzdesi ve yoğunluğu değerlendirildi. Neoplastik hücrelerde $\% 1$ ve üzerindeki boyanma pozitif kabul edildi. Ki-67 proliferasyon indeksi, sıcak noktaları içeren invaziv tümör hücrelerinin yüzdesine göre değerlendirildi. HER 2 durumu, +3 puan alan tümörler için pozitif, 0 ve +1 puan alan tümörler için negatif olarak tanımlandı. +2 skoru olan tümörlerde, HER 2 durumunu doğrulamak için Floresan in situ Hibridizasyon (FISH) değerleri hastane kayıt sisteminden elde edildi. Moleküler alt tiplendirme ER, PR, HER2 ve ki-67 değerleri kullanılarak yapıld1. Triple negatif grup, ER, PR ve HER2 negatif olarak tanımland1. ER ve PR negatif, HER2 pozitif ise HER2 zengin grup olarak sinıflandırıldı. Luminal A ve Luminal B ayrımında ki-67 değeri kullanıldı. Luminal A, ER ve/veya PR pozitif, HER2 negatif, Ki 67 değeri düşük $(<\% 20)$ olarak tanımland1. Luminal B hastaları ER ve/veya PR pozitif, HER2 negatif, Ki 67 değeri yüksek ( $\geq \% 20$ ) veya ER ve/veya PR pozitif, HER2 pozitif, herhangi bir Ki 67 değeri olarak tanımlandi (14).

$\mathrm{Bu}$ çalışmada istatiksel analizler IBM SPSS, 22. versiyon istatistik programı ile yapılmıştır. Verilerin değerlendirilmesinde tanımlayıc1 istatistiksel metotlar (ortalama, standart sapma, sıklık ve yüzde dağılımları) kullanılmıştır.

Çalışma 1964 Helsinki Bildirisi'nde belirtilen etik standartlarına göre yapıldı. Çalışmamızda araştırma ve yayın etiğine uyulmuştur. Bu çalışma için Etik Komite Onayı Sağlık Bakanlığı Ankara Eğitim ve Araştırma Hastanesi Klinik Araştırmalar Etik Kurul Başkanlığından E-20 sayılı 251 no'lu çalışma olarak 21.04.2020 tarihinde alınmıştır.

\section{BULGULAR}

İnvaziv meme kanserli en küçük hasta yaşı 25 , en büyük 40 olmakla birlikte yaş ortalaması $35.3 \pm 3.4$ yıl olarak saptand1. İnvaziv tümörün \%59.7'si sağ memede, \%40.3'ü sol memede izlendi. Histolojik olarak $65(\% 90.3)$ spesifiye edilemeyen duktal karsinom en yaygın tip, $4(\% 5,6)$ invaziv lobüler 
karsinom, 2 Mikropapiller ve 1 Apokrin özellikler gösteren invaziv karsinom saptandı. Tümör büyüklüğü \%27.8'i $2 \mathrm{~cm}$ altında izlenirken, $\% 58.3$ 'ü $2-5 \mathrm{~cm}$ arası ve $\% 13.9$ 'u $5 \mathrm{~cm}$ üzerindedir. Hastaların \%87.5'inde ER pozitifliği, \%73.6'sında PR pozitifliği, \%83.3'ünde HER2 negatifliği gözlendi. Olguların \%52.8'inde proliferasyon indeksi 20 ve üzerinde izlendi. Histolojik olarak yüksek grade, düşük bilateralite oranı izlendi. Hastaların 6'sında kemik metastazı, 2'sinde beyin metastazı mevcuttur. Sadece 1 olgu bilateral olup 5 olguda multisentrisite izlenmiştir. Moleküler sınıflamada 31 (\%43.1) Luminal A, 32 (\%44.4) Luminal B, 3 (\%4.2) HER2 ve $6(\% 8.3)$ triple negatif olarak tespit edildi. 32 Luminal B vakanın 8'i HER2 pozitifliği göstermektedir (Tablo I).

Tablo I. Patolojik ve İmmünhistokimyasal özellikler

\begin{tabular}{|c|c|}
\hline $\begin{array}{l}\text { Median yaş, }(\mathrm{y} 1++\mathrm{SD}) \\
\text { Minimum } \\
\text { Maksimum }\end{array}$ & $\begin{array}{l}35.3 \pm 3.4 \\
25 \\
40\end{array}$ \\
\hline $\begin{array}{l}\text { Lokalizasyon, } \mathrm{n}(\%) \\
\text { Sağ } \\
\text { Sol } \\
\end{array}$ & $\begin{array}{l}43(59.7) \\
29(40.3) \\
\end{array}$ \\
\hline $\begin{array}{l}\text { Histolojik tip, n(\%) } \\
\text { Duktal } \\
\text { Lobüler } \\
\text { Diğer } \\
\end{array}$ & $\begin{array}{l}65(90.3) \\
4(5.5) \\
3(4.2) \\
\end{array}$ \\
\hline $\begin{array}{l}\text { Tümör boyutu, } \mathrm{n}(\%) \\
\text { T1 } \leq 2 \mathrm{~cm} \\
\text { T2 }>2 \mathrm{~cm} \leq 5 \mathrm{~cm} \\
\text { T3 }>5 \mathrm{~cm}\end{array}$ & $\begin{array}{l}20(27.8) \\
42(58.3) \\
10(13.9) \\
\end{array}$ \\
\hline Pozitif lenf nodu, n(\%) & $42(58,3)$ \\
\hline $\begin{array}{l}\text { Östrojen, } \mathrm{n}(\%) \\
\text { Negatif } \\
\text { Pozitif } \\
\end{array}$ & $\begin{array}{l}9(12.5) \\
63(87.5)\end{array}$ \\
\hline $\begin{array}{l}\text { Progesteron, } n(\%) \\
\text { Negatif } \\
\text { Pozitif } \\
\end{array}$ & $\begin{array}{l}19(26.4) \\
53(73.6)\end{array}$ \\
\hline $\begin{array}{l}\text { HER2/neu, n(\%) } \\
\text { Negatif } \\
\text { Pozitif }\end{array}$ & $\begin{array}{l}60(83.3) \\
12(16.7)\end{array}$ \\
\hline $\begin{array}{l}\text { Ki-67, n (\%) } \\
<20 \\
\geq 20\end{array}$ & $\begin{array}{l}34(47.2) \\
38(52.8)\end{array}$ \\
\hline $\begin{array}{l}\text { Histolojik grade, } \mathrm{n}(\%) \\
1 \\
2 \\
3 \\
\end{array}$ & $\begin{array}{l}3(4.2) \\
31(43.1) \\
38(52.8)\end{array}$ \\
\hline Bilateralite, $\mathrm{n}(\%)$ & $1(1.3)$ \\
\hline Multisentrisite, $\mathrm{n}(\%)$ & $5(6.3)$ \\
\hline Uzak organ metastaz, $\mathbf{n}(\%)$ & $8(10.1)$ \\
\hline $\begin{array}{l}\text { Moleküler siniflama, n(\%) } \\
\text { Luminal A } \\
\text { Luminal B } \\
\text { HER 2 } \\
\text { Triple negatif }\end{array}$ & $\begin{array}{l}31(43.1) \\
32(44.4) \\
3(4.2) \\
6(8.3)\end{array}$ \\
\hline
\end{tabular}

SD: Standart deviasyon

Hastaların 16(\%22.2)'sinda ailede meme ve/veya over kanser öyküsü mevcuttur.

\section{TARTIŞMA}

Genç kadınlarda meme kanserleri yaş grubuna göre nadir görülmekle birlikte, radikal mastektomi, erken menopoz, infertilite başta olmak üzere çok fazla psikolojik sorunları da beraberinde getirmektedir (15). Gençlerde izlenen karsinomlar, yaşlı kadınlarda bulunan malignitelere göre biyolojik olarak daha agresif, yüksek tümör derecesine, daha fazla vasküler invazyona ve yüksek proliferasyon kapasitesine sahip olma eğilimindedir (4). Bazı çalışmalar genç yaşın bağımsız prognostik faktör olabileceğini bildirmiştir (16).

Bizim çalışmamızda ortalama yaş 35.3 olarak izlendi ve en yaygın histolojik tip invaziv duktal karsinom olarak saptandi. Olguların çoğu yüksek gradeli olarak gözlendi. 2956 hastayı kapsayan geniş serilerde yapılan bir çalışmada, tanı konulan medyan yaş 36, olguların büyük birçoğunda histolojik tip spesifiye edilemeyen duktal karsinom $(\% 86,5)$ ve yüksek histolojik grade $(\% 58,9)$ saptanmıştır $(17)$.

Meme kanserinin kalıtsal özellik gösterdiği ve meme kanserine yatkınlıktan sorumlu tutulan bazı genler tespit edilmiştir. BRCA1 ve BRCA2 germline mutasyonları ile meme kanseri gelişimi arasında güçlü bir ilişki olduğu gösterilmiştir. Ayrıca, BRCA1 ve BRCA2 mutasyonlarının over, tuba ve periton kanseri riskini, özellikle BRCA2 mutasyonlarının ise erkeklerde meme kanseri, pankreas kanseri ve melanoma riskini artırdığı bildirilmektedir (18). Bunlar kalıtsal meme ve over kanseri sendromu (HBOC) adı altında incelenmektedir (19). BRCA1 ve BRCA2 mutasyonları, özellikle erken başlangıçlı meme kanseri, bilateral meme kanseri, triple negatif meme kanseri veya ailede meme kanseri öyküsü olan kişilerde sıklıkla görülmektedir. Çalışmamızda \%22.2 oranında ailede meme ve/veya over kanser öyküsü mevcuttur. Çoğu hastanın BRCA1 ve BRCA2 mutasyon verileri olmadığından değerlendirilemedi.

Genç kadınlarda meme glandüler parankiminin yoğunluğundan dolayı radyolojik olarak normal meme ve tümör dokusunu ayırt etmek zordur. Bu yüzden gençlerde izlenen meme tümörleri büyük boyutta, lenf nod pozitifliği ve ileri evrede tanı almaktadır (17). Yapılan bir çalışmada genç kadınlarda izlenen ortalama tümör çap1 48,8mm olarak bildirilmiştir (20). Bu tümör büyüklüğü ileri yaş grubunda görülen meme kanseri olgularındaki tümör çapı ile kıyaslandığında çok daha geç tanı konulduğunu göstermektedir. Farklı bir çalışmada ise 35 yaş altı ve üstü kadınların \%67-73'ünde tümör boyutu $2-5 \mathrm{~cm}$ arasında bildirilmiş (21). Bu çalışmada benzer şekilde \%58.3 oranında tümör çapı $2-5 \mathrm{~cm}$ arası, $\% 13.9$ 'da $5 \mathrm{~cm}$ üzeri olmak üzere $\% 72.2$ oranında büyük boyutta tümör izlendi ve \%58.3'ünde tanı anında lenf nod pozitifliği saptandi.

Çalışmamızda olguların çoğunda ER ve PR pozitif izlenirken, HER2 negatif saptanmıştır. Yapılan bir çalışmada 40 yaş altı genç kadınlarda yaşlı kadınlara oranla anlamlı derecede negatif hormon reseptör düzeyi saptamışlar (22). Bununla birlikte farklı bir çalışmada yaşı kadınların gençlere göre daha fazla oranda hormon reseptör pozitifliğinin olduğu, ancak farkın anlamlı düzeyde olmadığı bildirilmiş (23). HER2/neu aşırı ekspresyonunun genç yaşta gelişen meme kanserlerinde lenf nod metastazlarında agresif immünfenotipin bir parçası olduğu bildirilmiş (24). Diğer çalışmalara paralel olarak yapılan geniş serili bir çalışmada daha agresif 
biyolojik alt tipler olan triple negatif ve HER2/neu + tümörlerin adölesan ve genç adultlarda izlenen tümörlerin büyük bir kısmını oluşturduğu saptanmış. Hormon reseptör pozitif gruptan sonra triple negatif ve hormon reseptör+/HER2/neu+ ve daha az olarak hormon reseptör-/HER2+ olarak saptanmış (25). Bu çalışmada hormon reseptör pozitif gruplar (Luminal B takiben Luminal A) en yüksek oranda izlenirken triple negatif ve HER2+ oranları daha düşük düzeyde kalmıştır. Bu durumun çalışma grubumuzun yeterli örneklem büyüklüğünü temsil etmemesinden kaynaklandığını düşünüyoruz.

Birçok çalışma hormon pozitif tümörlerde ki-67 boyanma oranına bakılarak kemoterapötik tedaviye yanıtı tahmin edebileceğini ve hastalık prognozu ile ilişkili olduğunu göstermiştir (26). Bizim çalışmamızda olguların yarısından fazlasında prediktif faktör olan Ki-67 proliferasyon indeksi $\% 20$ 'nin üzerinde izlendi. Lokal nüks ve uzak organ metastazı gibi prognoz üzerine önemli etkisi bulunan bilateralite ve multisentrisite oranı bizim çalışmamızda düşük bulunmuştur. Ayrıca 6 olguda kemik ve 2 olguda beyin metastazı izlendi.

\section{SONUÇ}

Meme kanseri olguları sıklıkla ileri yaş grubunda görülmesine rağmen, genç yaşta görülme sıklığında artış eğilimi görülmektedir. Gençlerde meme glandüler doku komponentinin fazla olması nedeni ile tarama testlerinin spesifitiesi ve sensivitesi yetersiz kalmaktadır. Bu nedenle bu yaş grubu meme kanserlerine ileri evrede tanıda konulabilmektedir. Ayrıca bu yaş grubunda görülen invaziv meme karsinom olgularında Ki67 değerinin yüksek, ER ve PR negatifliği ve HER2/neu pozitiflik oranının ileri yaşa göre daha fazla olmasının tedaviye direnç ve kötü prognoz ile ilişkili olduğu düşünülmektedir. $\mathrm{Bu}$ nedenle invaziv meme kanseri tanısı alan genç kadınlarda tümörün daha agresif ve kötü prognoz göstermesi yanı sıra, doğurganlık, tedaviye bağlı menopoz, cinsellik, benlik imajının zarar görmesi ve üreme fonksiyon kaybına bağlı kaygılar oldukça yüksek düzeyde olduğundan bu hastaların tanısında daha agresif yaklaşımlara gereksinim olduğu düşünülmektedir.

\section{YAZAR KATKI}

$\begin{array}{ll}\text { Fikir/kavram } & \text { : P.C., S.C. } \\ \text { Tasarım } & \text { : P.C., İB. } \\ \text { Denetleme/Danışmanlık } & \text { : P.C., S.C. } \\ \text { Veri toplama/ veya İşleme } & \text { : P.C., İB. } \\ \text { Analiz veya yorum } & \text { : P.C., S.C. } \\ \text { Kaynak taraması } & \text { : P.C., İ.B. } \\ \text { Makalenin yazımı } & \text { : P.C. } \\ \text { Eleştirel inceleme } & \text { : S.H. }\end{array}$

Etik komite onayı:Bu çalışma için Etik Komite Onayı Sağlık Bakanlığı Ankara Eğitim ve Araştırma Hastanesi Klinik Araştırmalar Etik Kurul Başkanlığından E-20 sayılı 251 no'lu çalışma olarak 21.04.2020 tarihinde alınmıştır.

Çıkar çatışması: Makalenin yazarları arasında çıkar çatışması bulunmamaktadır.

Finansman veya Mali Destek: Bu çalışmada finansman veya mali destek alınmamıştır. 


\section{Kaynaklar:}

1- Mehrabi E, Hajian S, Simbar M, Hoshyari M, Zayeri F. Coping response following a diagnosis of breast cancer: A systematic review. Electronic physician 2015; 7(8): 1575.

2- Assi HA, Khoury KE, Dbouk H, Khalil LE, Mouhied dine TH, El Saghir NS. Epidemiology and prognosis of breast cancer in young women. J ThoracDis 2013; 5(1): S2-8.

3- Reyna C, Lee MC. Breastcancer in young women: special considerations in multidisciplinary care. Journal of multidisciplinary healthcare 2014; 7: 419-29.

4- Chung M, Chang HR, Bland KI, Wanebo HJ. Younger women with breast carcinoma have poorer prognosth an older women. Cancer 1996; 77: 97-103.

5- Gajdos C, Tarrter PI, Bleiweiss IJ, Bodian C, Brower ST. Stage 0 tostage III breast cancer in young women. J AmColl Surg 2000; 190: 523-9.

6- Azim HA, Partridge AH. Biology of breast cancer in young women. Breast Cancer Res 2014; 16: 427.

7- Fredholm H, Eaker S, Frisell J, Holmberg L, Fredriksson I, Lindman H. Breast cancer in young women: poor survival despite intensive treatment. PLoSOne 2009; 4:e7695.

8- Cancello G, Maisonneuve P, Rotmensz N, Viale G, Mast ropasqua MG, Pruneri G, Veronesi P, Torrisi R, Montag na E, Luini A, Intra M, Gentilini O, Ghisini R, Gold hirsch A, Colleoni M. Prognosis and adjuvant treatment effects in selected breast cancer subtypes of very young women $(<35$ years) with operable breast cancer. AnnOn col 2010; 21: 1974-1981.

9- Han W, Kang SY. Relationship between age at diagnosis and outcome of premenopausal breast cancer: ageless than 35 years is a reason ablecut-off for defining young age-onset breast cancer. Breast Cancer Res Treat 2010; 119:193-200.

10- Azim HA Jr, Michiels S, Bedard PL, Singhal SK, Crisci tiello C, Ignatiadis M, Haibe-Kains B, Piccart MJ, Sotiri ou C, Loi S. Elucidating prognosis and biology of breast cancer arising in young women using gene expression profiling. Clin Cancer Res 2012; 18:1341-1351.

11- Maughan KL, Lutterbie MA, Ham PS. Treatment of breast cancer. Am Fam Physician 2010; 81(11): 1339-46.

12- Januškevičienè I, PetrikaitèV. Heterogeneity of breast cancer: the importance of interaction between different tumor cell populations. Life Sci 2019 Oct 24;239:117009.

13- Elston CW, Ellis IO. Pathological prognostic factors in breast cancer. I. The value of histological grade in breast cancer: experience from a large study with long-term follow-up. Histopathology. 1991; 19: 403-10

14- Goldhirsch A, Winer EP, Coates AS, et al. Personalizing the treatment of women with early breast cancer: highlights of the St Gallen International Expert Consen sus on the Primary Therapy of Early Breast Cancer 2013.
Ann Oncol 2013; 24: 2206-23.

15- Ali A, Fergus K, Wright FC, Pritchard KI, Kiss A, Warner E. The impact of a breast cancer diagnosis in young women on their relationship with their mothers. Breast. 2014; 23: 50-5.

16- Chen HL, Zhou MQ, Tian W, Meng KX, He HF. Effect of age on breast cancer patient prognoses: a popula tion-based study using the SEER 18 database. PLoS One 2016; 11(10): e0165409.

17- Copson E, Eccles B, Maishman T, Gerty S, Stanton L, Cutress RI, Altman DG, Durcan L, Simmonds P, Lawrence G, Jones L, Bliss J, Eccles D. POSH Study Steering Group: Prospective observational study of breast cancer treatment outcomes for UK women aged 18-40 years at diagnosis: the POSH study. J Natl Cancer Inst 2013; 105: 978-988.

18- Grignol VP, Agnese DM. Breast Cancer Genetics for the Surgeon: An Update on Causes and Testing Options. Journal of the American College of Surgeons 2016; 222(5): 906-914.

19- Newman B, Austin MA, Lee M, King MC. Inheritance of human breast cancer: evidence for autosomal dominant transmission in highrisk families. Proceedings of the National Academy of Sciences 1988; 85(9): 3044-3048.

20- Reza YC, Hajian-Tilaki K, Sharbatdaran M. Compari son of pathologic characteristics of breast cancer in younger and older women. Caspian J InternMed 2019; 10(1): 42-47.

21- Henouda S, Bensalem A, Rouabah L. Breast Carcinoma in Younger Algerian Eastern Women: Epidemiological Profile in Series of 135 Cases. ScienceResearch 2015; 3(4): 198-205

22- Hariharan N, Rao TS, Naidu CK, Raju KVVN, Rajappa S, Ayyagari S, Krishnamohan MVT, Murthy S, Suryade vara A, Boleneni N. The Impact of Stage and Molecular Subtypes on Survival Outcomes in Young Women with Breast Cancer. J Adolesc Young Adult Oncol 2019; 8(5): 628-634.

23- Erić I, Petek Erić A, Kristek J, Koprivčić I, Babić M. Breast cancer in young women: pathologic and immuno histochemical features. Acta Clin Croat 2018; 57(3): 497-502.

24- Agrup M, Stal O, Olsen K, Wingren S. C-erbB-2 overex pression and survival in early onset breast cancer. Breast Cancer Res Treat 2000; 63(1): 23-9.

25- Murphy BL, Day CN, Hoskin TL, Habermann EB, Boughey JC. Adolescents and Young Adults with Breast Cancer have More Aggressive Disease and Treatment Than Patients in Their Forties. Ann Surg Oncol 2019; 26(12): 3920-3930.

26- Yoshioka T, Hosoda M, Yamamoto M, Taguchi K, Hatanaka KC, Takakuwa E, Hatanaka Y, Matsuno Y, Yamashita H. Prognostic significance of pathologic complete response and Ki67 expression after neoadju vant chemotherapy in breast cancer. Breast Cancer 2015; 22(2): 185-91. 